\title{
Faktor-Faktor yang Mempengaruhi Auditor dalam Menilai Kualitas Audit Pada Kantor Akuntan Publik Di Kota Palembang
}

\author{
Poppy Indriani ${ }^{1}$ \\ Universitas Bina Darma \\ Email: poppy.indriani@binadarma.ac.id \\ Rolia Wahasusmiah ${ }^{2}$ \\ Universitas Bina Darma \\ Email: rolia.wahasusmiah@binadarma.ac.id
}

\begin{abstract}
This study was conducted to obtain empirical evidence regarding the factors that influence auditors in assessing audit quality at the Public Accountant Office in Palembang. The respondents of this study were all staff auditors (senior auditors and junior auditors) at 8 Public Accountant Offices in Palembang that were registered with the Ministry of Finance of the Republic of Indonesia with 43 auditors. The sample selection method in this study was determined by the purposive sampling method. The analysis technique used is multiple linear regression analysis. The independent variables in this study are independence, competence, auditor experience, accountability, professional ethics, time budget pressure, task complexity and due professional care. The dependent variable in this study is audit quality. the results of this study indicate that the variables of independence, competence, accountability, and professional ethics have a positive effect on audit quality, then the auditor experience and due professional care variables indicate that there is no effect on audit quality, whereas for time budget pressure and task complexity variables negatively affect quality an audit.
\end{abstract}

Keywords: Independence, Competence, Auditor Experience, Accountability, Professional

Ethics, Audit Fee, Time Budget Pressure, Task Complexity, Due Professional Care, Audit Quality.

\begin{abstract}
Abstrak
Penelitian ini dilakukan untuk memperoleh bukti empiris mengenai faktor-faktor yang mempengaruhi auditor dalam menilai kualitas audit pada Kantor Akuntan Publik di Palembang. Responden penelitian ini adalah seluruh staf auditor (auditor senior dan auditor junior) pada 8 Kantor Akuntan Publik di Kota Palembang yang terdaftar di Kementerian Keuangan Republik Indonesia dengan jumlah auditor sebanyak 43 orang. Metode pemilihan sampel pada penelitian ini ditentukan dengan metode purposive sampling. Teknik analisis yang digunakan adalah analisis regresi linier berganda. Variabel-variabel independen pada penelitian ini adalah independensi, kompetensi, pengalaman auditor, akuntabilitas, etika profesi, time budget pressure, kompleksitas tugas dan due professional care. Variabel dependen pada penelitian ini adalah kualitas audit. hasil penelitian ini menunjukkan bahwa variabel independensi, kompetensi, akuntabilitas, dan etika profesi berpengaruh positif terhadap kualitas audit, selanjutnya pada variabel pengalaman auditor dan due professional care menunjukkan bahwa tidak berpengaruh terhadap kualitas audit, sedangkan untuk variabel time budget pressure dan kompleksitas tugas berpengaruh negatif terhadap kualitas audit.
\end{abstract}

Kata kunci: Independensi, Kompetensi, Pengalaman Auditor, Akuntabilitas, Etika Profesi, Fee Audit, Time Budget Pressure, Kompleksitas Tugas, Due Professional Care, Kualitas Audit. 


\section{Pendahuluan}

Standar audit yang digunakan pada saat pelaksanaan audit akan memberikan dasar yang memadai bagi auditor untuk memberikan pendapat atas laporan keuangan auditan. Selain standar auditing, seorang auditor dalam menjalankan tugasnya juga harus mematuhi prinsip etika profesi dimana prinsip tersebut mengarahkan auditor dalam memenuhi tanggung jawab profesionalnya bahkan dengan mengorbankan keuntungan pribadinya.

Hal-hal tersebut diatas dijalankan oleh auditor untuk tetap bekerja dengan menghasilkan audit yang berkualitas. Kualitas audit ini sangat penting karena semakin tinggi kualitas audit, maka akan menghasilkan laporan keuangan yang dapat dipercaya sebagai dasar dalam proses pengambilan keputusan yang tepat. Kualitas audit yaitu segala kemungkinan dimana seorang auditor dapat menemukan pelanggaran maupun kecurangan yang terjadi, dan kemudian melaporkannya dalam bentuk laporan keuangan auditan (Ashari, 2011).

Namun didalam pelaksanaannya, telah banyak terjadi penyimpangan dalam pelaksanaan audit yang melibatkan akuntan publik, sebagai contoh pada perusahaan Raden Motor yang memiliki pinjaman modal sebesar Rp 52 miliar kepada Bank BRI Cabang Jambi, yang diduga terkait dengan kasus korupsi dalam kredit macet dimana terdapat keterlibatan Biasa Sitepu sebagai akuntan publik dalam kasus ini. Ditemukannya kesalahan dalam laporan keuangan Perusahaan Raden Motor dalam mengajukan pinjaman ke Bank BRI, karena terdapat empat kegiatan laporan keuangan milik Raden Motor yang tidak dimasukkan kedalam laporan keuangan yang akan diajukan ke BRI sehingga hal tersebut menjadi temuan bahwa terdapat kesalahan dalam proses kreditnya. (https://regional.kompas.com)

Sebagai seorang akuntan publik Biasa Sitepu telah melanggar prinsip kode etik yang telah ditetapkan oleh Kantor Akuntan Publik (KAP). Akibat dari banyaknya fenomena pelanggaran yang melibatkan akuntan publik, maka kualitas audit yang akan dihasilkan oleh akuntan publik tersebut akan mendapatkan sorotan dari masyarakat, karena banyak masyarakat yang mulai meragukan kualitas audit itu sendiri. Seperti kasus diatas, telah terjadi pelanggaran yang dilakukan oleh seorang akuntan publik di Jambi, dimana akuntan publik dituntut untuk dapat mendeteksi apabila terjadi kekeliruan dan kecurangan dalam laporan keuangan, akan tetapi yang dilakukan oleh akuntan publik tersebut malah ikut membantu untuk memalsukan laporan keuangan kliennya dengan tidak memasukkan empat kegiatan yang seharusnya dimasukkan kedalam laporan keuangan Raden Motor.

Kualitas audit ini merupakan suatu isu yang kompleks, hal tersebut dikarenakan banyak faktor yang dapat mempengaruhi tinggi rendahnya kualitas audit tersebut. Tinggi rendahnya kualitas audit dipengaruhi oleh banyak faktor, dimana dalam penelitian ini faktor-faktor yang diasumsikan memiliki pengaruh terhadap kualitas audit adalah independensi, kompetensi, pengalaman auditor, akuntabilitas, etika profesi, time budget pressure, kompleksitas tugas dan due professional care.

Berdasarkan beberapa penjelasan diatas, maka penulis tertarik untuk melakukan penelitian yang berjudul Analisis Faktor-Faktor yang Mempengaruhi Auditor dalam Menilai Kualitas Audit Pada Kantor Akuntan Publik di Palembang.

\section{Literature Review}

\subsection{Pengaruh Independensi Terhadap Kualitas Audit}

Independensi merupakan syarat penting bagi auditor dalam melaksanakan prosedur audit yang bertujuan untuk menilai kewajaran laporan keuangan. Semua hal yang berhubungan dengan perikatan, independensi dalam sikap mental harus dipertahankan oleh auditor (PSA No.4 SA Seksi 220). Untuk itu seorang auditor sebaiknya bersikap bebas tanpa memihak dari kepentingan pihak lain, sehingga mampu menerapkan standar-standar dan prinsip-prinsip audit dalam pekerjaan audit yang dapat menghasilkan kualitas audit yang baik dimana opini yang dikeluarkan dapat menambah kredibilitas laporan keuangan yang telah disajikan oleh manajemen. Berdasarkan landasan teoritis dan hasil-hasil penelitian yang telah dikemukakan sebelumnya, maka hipotesis yang diajukan adalah: 
$H_{1}$ : Independensi berpengaruh positif terhadap Kualitas Audit.

\subsection{Pengaruh Kompetensi Terhadap Kualitas Audit}

Kualitas audit sering kali dihubungkan dengan kompetensi yang dimiliki auditor, sehingga dalam menghasilkan kualitas audit yang tinggi seorang auditor dapat menggunakan kompetensi yang dimilikinya dalam melakukan pekerjaan audit. Hal tersebut dikarenakan seorang auditor yang memiliki pengetahuan dan pengalaman yang memadai akan lebih memahami dan mengetahui berbagai masalah secara lebih mendalam. Berdasarkan landasan teoritis dan hasil-hasil penelitian yang telah dikemukakan sebelumnya, maka hipotesis yang diajukan adalah:

$\mathrm{H}_{2}$ : Kompetensi berpengaruh positif terhadap Kualitas Audit.

\subsection{Pengaruh Pengalaman Auditor Terhadap Kualitas Audit}

Banyaknya pengalaman yang dimiliki seorang auditor maka auditor akan lebih banyak mengetahui ragam permasalahan dalam hal auditing, dimana pengalaman akan memberikan berbagai pengaruh dalam berbagai pertimbangan pengambilan keputusan dan juga penyelesaian masalah yang dihadapi auditor, sehingga diharapkan setiap keputusan yang diambil merupakan keputusan yang tepat. Selain itu, pengalaman juga dapat membuat auditor menyelesaikan masalah dengan lebih cepat dan lebih baik, hal ini dikarenakan seringnya auditor melakukan pekerjaan yang sama secara berulang-ulang sehingga akan semakin mengasah keahliannya dalam mendeteksi suatu hal sehingga terbentuk penyelesaian pekerjaan yang semakin cepat. Berdasarkan landasan teoritis dan hasil-hasil penelitian yang telah dikemukakan sebelumnya, maka hipotesis yang diajukan adalah:

$\mathrm{H}_{3}$ : Pengalaman berpengaruh positif terhadap Kualitas Audit.

\subsection{Pengaruh Akuntabilitas Terhadap Kualitas Audit}

Motivasi, pengabdian pada profesi, dan komitmen yang terbentuk dalam diri seorang auditor untuk menyelesaikan kewajibannya tanpa paksaan dari siapapun merupakan perwujudan dari akuntabilitas, dimana kewajiban seorang auditor untuk mempertanggungjawabkan setiap tugas yang diembannya kepada rekan seprofesi dan lingkungannya membuat akuntabilitasnya semakin tinggi. Hal tersebut membuat auditor terpacu untuk menyelesaikan tugasnya dengan baik karena mendapat tanggungjawab yang besar sehingga kualitas audit yang dihasilkannya akan meningkat (Ratha dan Ramantha, 2015). Berdasarkan landasan teoritis dan hasil-hasil penelitian yang telah dikemukakan sebelumnya, maka hipotesis yang diajukan adalah:

\section{$H_{4}$ : Akuntabilitas berpengaruh positif terhadap Kualitas Audit}

\subsection{Pengaruh Etika Profesi Terhadap Kualitas Audit}

Akuntan yang profesional dalam menjalankan tugasnya memiliki pedoman-pedoman yang mengikat seperti kode etik dalam hal ini adalah Kode Etik Akuntan Indonesia, sehingga dalam melaksanakan aktivitasnya akuntan publik memiliki arah yang jelas dan dapat memberikan keputusan yang tepat, dimana keputusan tersebut dapat dipertanggungjawabkan kepada pihak-pihak yang menggunakan hasil keputusan auditor tersebut (Hanjani dan Rahardja, 2014). Oleh karena itu, untuk menghasilkan audit yang berkualitas maka seorang auditor dalam melaksanakan pekerjaan audit nya harus selalu berdasarkan pada etika profesi. Auditor yang menerapkan etika profesi dengan bekerja sesuai dengan standar pelaksanaan audit, maka akan menghasilkan kualitas audit yang baik (Ridhawati, 2018). Berdasarkan landasan teoritis dan hasil-hasil penelitian yang telah dikemukakan sebelumnya, maka hipotesis yang diajukan adalah:

$H_{5}$ : Etika profesi berpengaruh positif terhadap Kualitas Audit 


\subsection{Pengaruh Time Budget Pressure Terhadap Kualitas Audit}

Time budget pressure atau tekanan anggaran waktu digunakan untuk mengukur tingkat efisiensi auditor dalam menyelesaikan pekerjaan auditnya, dimana ketepatan waktu dalam menyelesaikan tugas audit merupakan komponen penting dalam penilaian kinerja auditor. Akan tetapi, keadaan yang seringkali memunculkan tekanan dalam diri auditor, dimana ketidaksesuaian antara time budget dengan tugas yang diberikan akan membuat timbulnya perilaku disfungsional yang akan menyebabkan rendahnya kualitas audit yang akan dihasilkan. Berdasarkan landasan teoritis dan hasilhasil penelitian yang telah dikemukakan sebelumnya, maka hipotesis yang diajukan adalah:

$H_{6}$ : Time budget pressureberpengaruh negatif terhadap Kualitas Audit

\subsection{Pengaruh Kompleksitas Tugas Terhadap Kualitas Audit}

Kompleksitas tugas merupakan tingkat kesulitan tugas dan struktur tugas yang diemban oleh seorang auditor. Adanya peningkatan kompleksitas dalam suatu tugas audit yang diemban auditor maka hal tersebut dapat mengakibatkan turunnya tingkat keberhasilan tugas dalam mendeteksi kecurangankecurangan yang mungkin terjadi dan pada akhirnya akan menjadi penyebab menurunnya kualitas audit yang dihasilkan selama proses pemeriksaan. Berdasarkan landasan teoritis dan hasil-hasil penelitian yang telah dikemukakan sebelumnya, maka hipotesis yang diajukan adalah:

$H_{7}$ : Kompleksitas tugas berpengaruh negatif terhadap Kualitas Audit

\subsection{Pengaruh Due Professional Care Terhadap Kualitas Audit}

Penggunaan due professional care dengan seksama dan cermat akan menuntut auditor untuk bersikap skeptis, dimana sikap skeptis ini mengharuskan auditor untuk berpikir kritis terhadap bukti audit yang ada dengan selalu mempertanyakan dan melakukan evaluasi terhadap bukti audit tersebut, berhati-hati dalam tugas, serta tidak ceroboh dalam melakukan pemeriksaan dan memiliki keteguhan dalam melaksanakan tanggungjawab sehingga akan meningkatkan keyakinan yang memadai pada auditor untuk memberikan opini bahwa laporan keuangan tersebut bebas dari salah saji material, baik yang disebabkan oleh kecurangan ataupun kekeliruan (Ridhawati, 2018). Berdasarkan landasan teoritis dan hasil-hasil penelitian yang telah dikemukakan sebelumnya, maka hipotesis yang diajukan adalah:

$H_{8}$ : Due Professional Care berpengaruh positif terhadap Kualitas Audit

\section{Metode Penelitian}

Objek penelitian yang digunakan dalam penelitian ini adalah auditor yang bekerja di Kantor Akuntan Publik di Kota Palembang yang terdaftar di Kementerian Keuangan Republik Indonesia yaitu sebanyak delapan KAP dengan jumlah auditor sebanyak 43 orang yang terdiri dari auditor senior dan auditor junior. Teknik analisis data dalam penelitian ini dilakukan dengan beberapa tahapan yaitu diawali dengan uji analisis statistik deskriptif dan uji kualitas data, dimana pada uji kualitas data ini terbagi menjadi dua yaitu uji validitas dan uji reliabilitas.

Kemudian dilanjutkan dengan uji asumsi klasik, dimana untuk mendeteksi adanya penyimpangan asumsi klasik maka dilakukan uji normalitas, uji multikolinearitas, dan uji heteroskedastisitas. Jika data telah lolos uji asumsi klasik, maka setelah itu dilanjutkan dengan analisis regresi linier berganda dan uji hipotesis. Pada uji hipotesis ini terbagi menjadi empat, yaitu diantaranya uji koefisien determinasi $\left(\mathrm{R}^{2}\right)$, uji koefisien korelasi (R), uji signifikansi parsial (uji-t) dan yang terakhir uji signifikansi simultan (uji-F). 


\section{Hasil dan Pembahasan}

\subsection{Uji Koefisien Determinasi $\left(R^{2}\right)$}

Koefisien determinasi $\left(\mathrm{R}^{2}\right)$ yaitu alat analisis yang digunakan untuk menunjukkan besarnya kontribusi dari variabel bebas atau independen (independensi, kompetensi, pengalaman auditor, akuntabilitas, etika profesi, time budget pressure, kompleksitas tugas, dan due professional care) dapat menjelaskan variabel dependen (kualitas audit).

Berikut ini tabel hasil uji koefisien determinasi:

Tabel 1 : Hasil Uji Koefisien determinasi $\left(\mathrm{R}^{2}\right)$

Model Summary

\begin{tabular}{|c|c|c|c|c|}
\hline Model & $\mathbf{R}$ & R Square & Adjusted R Square & $\begin{array}{c}\text { Std. Error of the } \\
\text { Estimate }\end{array}$ \\
\hline 1 &, $764^{\mathrm{a}}$ & ,584 & ,486 & 3,12768 \\
\hline
\end{tabular}

Sumber : Data primer yang diolah, 2019

Berdasarkan tabel hasil uji $\left(\mathrm{R}^{2}\right)$ tersebut, dapat dilihat pada tabel Model Summary dengan melihat nilai $R$ square sebesar 0,584 atau $58,4 \%$. Hal ini berarti variabel independensi, kompetensi, pengalaman auditor, akuntabilitas, etika profesi, time budget pressure, kompleksitas tugas, dan due professional care secara bersama-sama dapat menjelaskan variabel dependen sebesar 58,4\%, sedangkan sisanya $41,6 \%(100 \%-58,4 \%=41,6 \%)$ kualitas audit dipengaruhi oleh variabel lain yang tidak dijelaskan dalam penelitian ini.

\subsection{Uji Koefisien Korelasi $(R)$}

Koefisien korelasi $(\mathrm{R})$ digunakan untuk mengukur keeratan hubungan antar variabel independen (independensi, kompetensi, pengalaman auditor, akuntabilitas, etika profesi, time budget pressure, kompleksitas tugas, dan due professional care) secara bersama-sama terhadap kualitas audit.

Tabel 2 : Hasil Uji Koefisien korelasi (R)

Model Summary

\begin{tabular}{|l|r|r|r|r|}
\hline Model & \multicolumn{1}{|c|}{ R } & R Square & Adjusted R Square & \multicolumn{1}{c|}{$\begin{array}{c}\text { Std. Error of the } \\
\text { Estimate }\end{array}$} \\
\hline 1 &, $764^{\mathrm{a}}$ &, 584 &, 486 & 3,12768 \\
\hline a. & \begin{tabular}{l} 
Predictors: (Constant), Due Professional Care, Time Budget Pressure, Kompetensi, \\
\multicolumn{3}{|l}{ Kompleksitas Tugas, Pengalaman Auditor, Independensi, Etika Profesi, Akuntabilitas }
\end{tabular} \\
\hline b. & \multicolumn{3}{l}{ Dependent Variable: Kualitas Audit } \\
\hline
\end{tabular}

Sumber : Data primer yang diolah, 2019

Berdasarkan tabel hasil uji koefisien korelasi (R) tersebut, dapat dilihat bahwa hubungan antara kualitas audit dengan variabel independensi, kompetensi, pengalaman auditor, akuntabilitas, etika profesi, time budget pressure, kompleksitas tugas, dan due professional care mempunyai hubungan 
yang erat, karena berdasarkan tabel koefisien korelasi 0,764 berada dikriteria 0,600 sampai dengan 0,799 .

\subsection{Uji Signifikansi Simultan (Uji F)}

Uji $\mathrm{F}$ ini digunakan untuk mengetahui apakah variabel bebas atau independen secara bersama-sama (simultan) berpengaruh signifikan terhadap variabel terikat (dependen). Pengujian dilakukan dengan menggunakan signifikan $0,05(\alpha=5 \%)$. Berikut ini tabel hasil uji signifikansi simultan:

Tabel 3 : Hasil Uji Signifikansi Simultan (Uji F)

ANOVA $^{\mathrm{a}}$

\begin{tabular}{|l|l|r|r|r|r|r|}
\hline \multicolumn{2}{|l|}{ Model } & \multicolumn{1}{c|}{ Sum of Squares } & df & Mean Square & F & \multicolumn{1}{c|}{ Sig. } \\
\hline 1 & Regression & 467,445 & 8 & 58,431 & 5,973 &, $000^{\mathrm{b}}$ \\
& Residual & 332,602 & 34 & 9,782 & & \\
& Total & 800,047 & 42 & & & \\
\hline
\end{tabular}

a. Dependent Variable: kualitas audit

b. Predictors: (Constant), due professional care, time budget pressure, kompetensi,

kompleksitas tugas, pengalaman auditor, independensi, etika profesi, akuntabilitas

Sumber : Data primer yang diolah, 2019

Berdasarkan hasil uji $\mathrm{F}$ diatas, $\mathrm{F}_{\text {hitung }}$ yang didapat pada penelitian ini adalah 5,973 . Hal ini berarti bahwa $F_{\text {hitung }}$ lebih besar dari $F_{\text {tabel }} 2,29(5,973>2,29)$ dengan signifikan 0,000 dimana nilai ini lebih kecil dari $0,05(0,000<0,05)$, maka $\mathrm{H}_{\mathrm{o}}$ ditolak dan $\mathrm{H}_{\mathrm{a}}$ diterima. Hal ini berarti bahwa variabel independensi, kompetensi, pengalaman auditor, akuntabilitas, etika profesi, time budget pressure, kompleksitas tugas, dan due professional care secara bersama-sama (simultan) berpengaruh signifikan terhadap kualitas audit.

\subsection{Uji Signifikansi Parsial (Uji t)}

Uji t digunakan untuk mengetahui ada atau tidaknya pengaruh signifikan secara parsial dari masingmasing variabel independen yaitu variabel Independensi $\left(\mathrm{X}_{1}\right)$, Kompetensi $\left(\mathrm{X}_{2}\right)$, Pengalaman Auditor $\left(\mathrm{X}_{3}\right)$, Akuntabilitas $\left(\mathrm{X}_{4}\right)$, Etika Profesi $\left(\mathrm{X}_{5}\right)$, Time Budget Pressure $\left(\mathrm{X}_{6}\right)$, Kompleksitas Tugas $\left(\mathrm{X}_{7}\right)$, dan Due Professional Care $\left(\mathrm{X}_{8}\right)$ terhadap variabel dependen yaitu variabel Kualitas Audit (Y). Dari pengujian hipotesis secara parsial diperoleh hasil yaitu sebagai berikut:

Tabel 4 : Hasil Uji Signifikansi Parsial (Uji t)

\begin{tabular}{|c|c|c|c|c|c|}
\hline \multirow[b]{3}{*}{ Model } & \multicolumn{3}{|c|}{ Coefficients $^{a}$} & \multirow[b]{3}{*}{$\mathrm{T}$} & \multirow[b]{3}{*}{ Sig. } \\
\hline & \multicolumn{2}{|c|}{$\begin{array}{l}\text { Unstandardized } \\
\text { Coefficients }\end{array}$} & $\begin{array}{l}\text { Standardized } \\
\text { Coefficients }\end{array}$ & & \\
\hline & B & Std. Error & Beta & & \\
\hline 1 (Constant) & 1.911 & 13.920 & & .137 & .892 \\
\hline Independensi & 1.177 & .305 & .500 & 3,863 & .000 \\
\hline Kompetensi & .339 & .127 & .335 & 2.662 & .012 \\
\hline Pengalaman Auditor & -.324 & .193 & -.249 & -1.678 & .102 \\
\hline Akuntabilitas & .398 & .204 & .301 & 1.953 & .059 \\
\hline Etika Profesi & .215 & .043 & .671 & 5.034 & .000 \\
\hline
\end{tabular}




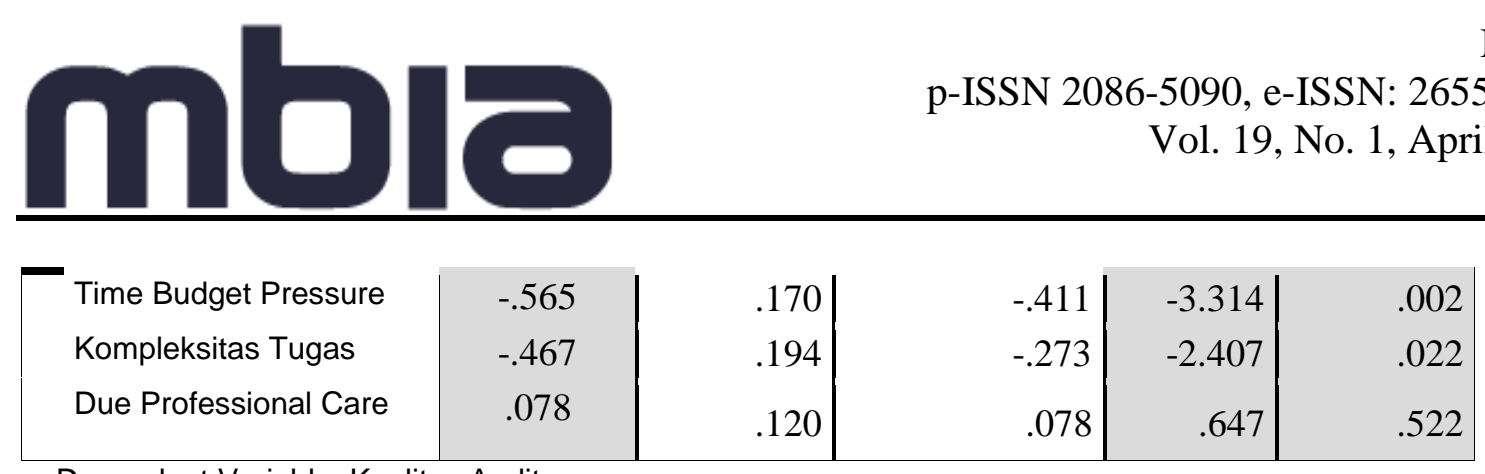

a. Dependent Variable: Kualitas Audit

Sumber : Data primer yang diolah, 2019

Setelah melakukan analisis regresi linier berganda dari tabel 2 diatas, maka nilai-nilai koefisien regresi tersebut dapat dimasukkan kedalam persamaan regresi yang disusun dalam persamaan regresi linier berganda sebagai berikut:

$$
\begin{aligned}
\mathrm{KA}= & 1,911+1,177 \mathrm{IND}+0,339 \mathrm{KO}-0,324 \mathrm{PA}+0,398 \mathrm{AK}+0,215 \mathrm{EP} \\
& -0,565 \mathrm{TBP}-0,467 \mathrm{KT}+0,078 \mathrm{DPC}+\mathrm{e}
\end{aligned}
$$

Berdasarkan hasil uji $\mathrm{t}$ (parsial) pada tabel 2 diatas, menunjukkan bahwa variabel independensi, kompetensi, akuntabilitas, dan etika profesi secara parsial berpengaruh positif terhadap kualitas audit, selanjutnya pada variabel pengalaman auditor dan due professional care menunjukkan bahwa secara parsial tidak berpengaruh terhadap kualitas audit, sedangkan untuk variabel time budget pressure dan kompleksitas tugas secara parsial berpengaruh negatif terhadap kualitas audit.

\subsection{Pembahasan}

Berikut ini adalah pembahasan dari hasil penelitian berdasarkan analisis yang sudah dilakukan:

\subsubsection{Pengaruh Independensi Terhadap Kualitas Audit}

Hasil penelitian ini mendukung dari hasil penelitian yang dilakukan oleh Ridhawati (2018) yaitu independensi berpengaruh positif signfikan terhadap kualitas audit. Hal ini mengindikasikan bahwa semakin tinggi independensi yang dimiliki auditor maka semakin tinggi juga kualitas audit. Hubungan antara independensi searah dengan pelaksanaan kualitas audit, yang berarti semakin baik independensi seorang auditor akan semakin baik kualitas audit. Sikap independensi dibutuhkan oleh seorang auditor agar dalam melakukan penugasan auditnya auditor dapat memeriksa secara bebas atau leluasa, dimana auditor memiliki kebebasan dalam mengumpulkan bukti-bukti audit dan informasi yang dibutuhkan tanpa mengesampingkan fakta-fakta yang ditemukan selama proses audit.

\subsubsection{Pengaruh Kompetensi Terhadap Kualitas Audit}

Hasil penelitian ini mendukung dari hasil penelitian yang dilakukan oleh Ridhawati (2018) yaitu kompetensi berpengaruh positif signifikan terhadap kualitas audit. Hal ini mengindikasikan bahwa semakin tinggi kompetensi yang dimiliki auditor maka semakin tinggi juga kualitas audit yang akan dihasilkan oleh auditor tersebut. Apabila seorang auditor memiliki pengalaman dan pengetahuan yang cukup, maka auditor tersebut akan mampu untuk menghasilkan kualitas audit yang maksimal dan sesuai dengan standar akuntansi keuangan yang berlaku sehingga membuat para pencari jasa auditor pun tidak akan ragu dalam mempercayakan pengauditan terhadap auditor tersebut.

\subsubsection{Pengaruh Pengalaman Auditor Terhadap Kualitas Audit}

Hasil penelitian ini tidak mendukung hasil penelitian yang dilakukan oleh Kamil (2018), dimana pada penelitian ini pengalaman auditor tidak berpengaruh terhadap kualitas audit. Hal ini mengindikasikan bahwa semakin tinggi atau semakin rendahnya pengalaman yang dimiliki auditor tidak berpengaruh terhadap kualitas audit yang akan dihasilkan oleh auditor tersebut. Baik auditor yang berpengalaman maupun yang tidak berpengalaman tidak berpengaruh terhadap kualitas audit, karena pengalaman 
yang dimiliki seorang auditor yang diperolehnya dari lamanya ia bekerja tidaklah cukup untuk dijadikan sebagai jaminan didalam menghasilkan laporan audit yang berkualitas, karena auditor yang memiliki pengalaman kerja lebih lama belum tentu dapat menguasai bidang yang dilakukannya, hal ini memungkinkan bila dilihat dari sikap masing-masing auditor tersebut. Ada pula auditor yang masih kurang berpengalaman dalam hal ini dilihat dari lamanya bekerja sebagai auditor serta banyaknya tugas atau pekerjaan yang dilakukan tetapi kualitas audit yang dihasilkannya lebih baik dari pada yang berpengalaman.

\subsubsection{Pengaruh Akuntabilitas Terhadap Kualitas Audit}

Hasil penelitian ini mendukung dari hasil penelitian yang dilakukan oleh Ridhawati (2018) yaitu akuntabilitas berpengaruh positif signifikan terhadap kualitas audit. Hal ini mengindikasikan bahwa semakin tinggi akuntabilitas yang dimiliki auditor maka kualitas audit dari auditor tersebut juga semakin tinggi. Apabila seorang auditor memiliki kesadaran akan betapa besar perannya bagi masyarakat dan bagi profesinya, maka auditor akan merasa memiliki kewajiban untuk memberikan yang terbaik bagi masyarakat dan terutama bagi profesinya tersebut dengan mengerahkan usaha yang lebih besar dalam menyelesaikan pekerjaannya sehingga kualitas audit yang dihasilkannya meningkat.

\subsubsection{Pengaruh Etika Profesi Terhadap Kualitas Audit}

Hasil penelitian ini mendukung dari hasil penelitian yang dilakukan oleh Ridhawati (2018) yaitu etika profesi berpengaruh positif signifikan terhadap kualitas audit. Hal ini mengindikasikan bahwa semakin tinggi etika profesi yang dimiliki auditor maka kualitas audit dari auditor tersebut juga semakin baik. Seorang akuntan dapat dikatakan profesional, apabila dalam menjalankan tugasnya sudah sesuai dengan aturan atau pedoman Kode Etik Akuntan Indonesia, dimana dengan adanya aturan tersebut maka auditor mempunyai arah yang jelas dan dapat memberikan keputusan yang tepat serta dapat dipertanggungjawabkan kepada pihak-pihak yang menggunakan hasil keputusan auditor tersebut.

\subsubsection{Pengaruh Time Budget Pressure Terhadap Kualitas Audit}

Hasil penelitian ini mendukung dari hasil penelitian yang dilakukan oleh Ridhawati (2018) yaitu time budget pressure berpengaruh negatif terhadap kualitas audit. Hal ini mengindikasikan bahwa semakin tinggi time budget pressure yang dibebankan kepada auditor maka akan menurunkan kualitas audit yang akan dihasilkan auditor. Apabila seorang auditor dituntut untuk menyelesaikan pekerjaan auditnya dengan batas waktu yang sangat ketat, maka akan memicu timbulnya perilaku disfungsional dalam diri auditor tersebut, dimana perilaku disfungsional ini akan membuat auditor mengurangi tingkat kepatuhannya dalam menjalankan prosedur audit sehingga akan menurunkan kualitas audit yang akan dihasilkan auditor tersebut.

\subsubsection{Pengaruh Kompleksitas Tugas Terhadap Kualitas Audit}

Hasil penelitian ini mendukung dari hasil penelitian yang dilakukan oleh Natawirani dan Wirajaya (2017) yaitu kompleksitas tugas berpengaruh negatif terhadap kualitas audit. Hal ini mengindikasikan bahwa semakin tinggi kompleksitas tugas yang dihadapi oleh seorang auditor maka kualitas auditnya semakin menurun. Adanya peningkatan kompleksitas dalam suatu tugas audit yang diemban oleh auditor, maka hal tersebut akan menimbulkan kesulitan tersendiri bagi auditor dalam menyelesaikan penugasan auditnya, yang pada akhirnya akan mendorong auditor untuk berperilaku disfungsional dan lebih mengutamakan kepentingan klien dari pada objektivitas dari hasil pengauditan itu sendiri sehingga menjadi penyebab menurunnya kualitas audit yang dihasilkan selama proses pemeriksaan. 


\subsubsection{Pengaruh Due Professional Care Terhadap Kualitas Audit}

Hasil penelitian ini tidak mendukung hasil penelitian yang dilakukan oleh Ridhawati (2018), dimana pada penelitian ini due professional care tidak berpengaruh terhadap kualitas audit. Hal ini mengindikasikan bahwa semakin tinggi atau semakin rendahnya due professional care tidak berpengaruh terhadap kualitas audit yang akan dihasilkan oleh auditor tersebut. Sikap due professional care yang dimiliki seorang auditor dalam melaksanakan pekerjaannya tidak bisa dijadikan dasar dalam menghasilkan laporan audit yang berkualitas, karena baik auditor yang memiliki sikap due professional caremaupun yang tidak memiliki sikap due professional care tidak berpengaruh terhadap kualitas dari laporan hasil audit itu sendiri. Hal ini dikarenakan seseorang dengan sikap due professional care yang tinggi belum tentu akan memiliki kebebasan dalam melakukan pekerjaannya tanpa adanya tekanan dari pihak lain, dimana tekanan dari pihak lain ini disebabkan oleh klien yang memberikan bukti-bukti yang kurang persuasive, sehingga adanya ketidakpuasan dalam diri auditor terhadap bukti-bukti yang kurang persuasive dari klien tersebut (Fitriani, 2016). Hal ini sesuai dengan jawaban responden yang banyak menyatakan setuju pada pernyataan auditor selalu tidak puas dengan bukti-bukti yang kurang persuasive dari kliennya.

\section{SIMPULAN}

Berdasarkan hasil penelitian dan pembahasan yang telah dilakukan mengenai "Analisis Faktor-Faktor Yang Mempengaruhi Auditor Dalam Menilai Kualitas Audit Pada Kantor Akuntan Publik Di Palembang", maka dapat ditarik kesimpulan sebagai berikut:

1. Hasil hipotesis pertama $\left(\mathrm{H}_{1}\right)$ menunjukkan bahwa independensi berpengaruh positif terhadap kualitas audit. Hal ini menunjukkan bahwa semakin independen seorang auditor maka semakin baik kualitas audit yang akan dihasilkannya.

2. Hasil hipotesis kedua $\left(\mathrm{H}_{2}\right)$ menunjukkan bahwa kompetensi berpengaruh positif terhadap kualitas audit. Dengan menjadi auditor yang berkompeten, maka para pencari jasa auditor pun tidak akan ragu dalam mempercayakan pengauditan terhadap auditor tersebut, dimana bagi seorang auditor sangatlah penting untuk meyakinkan klien dan pemakai laporan keuangan akan kualitas hasil kerja auditor tersebut.

3. Hasil hipotesis ketiga $\left(\mathrm{H}_{3}\right)$ menunjukkan bahwa pengalaman auditor tidak berpengaruh terhadap kualitas audit. Hal ini menunjukkan bahwa auditor yang berpengalaman maupun yang tidak berpengalaman tidak berpengaruh terhadap kualitas audit yang akan dihasilkan auditor tersebut. Pengalaman seorang auditor bukan menjadi faktor yang berpengaruh besar dalam menghasilkan kualitas audit. Hal ini dikarenakan bahwa auditor yang tidak berpengalaman juga mampu menghasilkan kualitas audit yang baik karena keahlian audit dan pengetahuan tentang audit yang dimilikinya.

4. Hasil hipotesis keempat $\left(\mathrm{H}_{4}\right)$ menunjukkan bahwa akuntabilitas berpengaruh positif terhadap kualitas audit. Hal ini menunjukkan bahwa auditor yang memiliki akuntabilitas tinggi akan bertanggungjawab penuh terhadap pekerjaannya sehingga kualitas audit yang akan dihasilkannya akan semakin baik. Adanya akuntabilitas pada diri auditor, maka akan membuat auditor tersebut berusaha mempertanggungjawabkan semua tindakan dan keputusan yang telah diambilnya.

5. Hasil hipotesis kelima $\left(\mathrm{H}_{5}\right)$ menunjukkan bahwa etika profesi berpengaruh positif terhadap kualitas audit. Hal ini menunjukkan bahwa auditor yang menjunjung tinggi etika profesi, maka akan semakin menunjukkan kepatuhannya terhadap aturan atau norma yang berlaku, sehingga kualitas audit yang akan dihasilkannya akan semakin baik. 
6. Hasil hipotesis keenam $\left(\mathrm{H}_{6}\right)$ menunjukkan bahwa time budget pressure berpengaruh negatif terhadap kualitas audit. Hal ini menunjukkan bahwa semakin tinggi time budget pressure yang dibebankan kepada auditor, maka akan menurunkan kualitas audit yang akan dihasilkan auditor tersebut dan sebaliknya. Keadaan yang seringkali terjadi yaitu ketidaksesuaian antara time budget yang telah ditetapkan oleh perusahaan dengan tugas yang diberikan, sehingga akan memicu timbulnya perilaku disfungsional dimana disfungsional ini membuat auditor mengurangi tingkat kepatuhannya dalam menjalankan prosedur audit sehingga akan menurunkan kualitas audit yang akan dihasilkan auditor tersebut.

7. Hasil hipotesis ketujuh $\left(\mathrm{H}_{7}\right)$ menunjukkan bahwa kompleksitas tugas berpengaruh negatif terhadap kualitas audit. Hal ini menunjukkan bahwa semakin tinggi kompleksitas tugas yang dibebankan kepada auditor, maka akan menurunkan kualitas audit yang akan dihasilkan auditor tersebut dan sebaliknya. Tingginya kompleksitas suatu tugas bisa menyebabkan seorang auditor berperilaku disfungsional, dimana auditor tersebut lebih mengutamakan kepentingan klien dari pada objektivitas dari hasil pengauditan itu sendiri.

8. Hasil hipotesis kedelapan $\left(\mathrm{H}_{8}\right)$ menunjukkan bahwa due professional care tidak berpengaruh terhadap kualitas audit. Hal ini menunjukkan bahwa semakin tinggi atau semakin rendahnya due professional care tidak berpengaruh terhadap kualitas audit yang akan dihasilkan oleh auditor tersebut karena sikap due professional care yang dimiliki seorang auditor bukanlah menjadi faktor yang berpengaruh besar dalam menghasilkan kualitas audit sehingga tidak bisa dijadikan jaminan bahwa laporan hasil audit yang akan dihasilkan auditor tersebut berkualitas.

\section{Daftar Pustaka}

Agusti, R., dan Pertiwi, N.P. (2013). Pengaruh Kompetensi, Independensi, dan Profesionalisme Terhadap Kualitas Audit (Studi Empiris Pada Kantor Akuntan Publik Se-Sumatera). Jurnal Ekonomi, 21(3).

Ashari, R. (2011). Pengaruh Keahlian, Independensi Dan Etika Terhadap Kualitas Auditor Pada Inspektorat Provinsi Maluku Utara. Skripsi.Fakultas Ekonomi. Universitas Hasanuddin. Makassar.

Fajjrin, F. (2018). Pengaruh Independensi, Pengalaman Kerja, Due Professional Care, Akuntabilitas, Dan Kompetensi Terhadap Kualitas Audit (Studi Empiris Pada Kantor Akuntan Publik Di Yogyakarta Dan Semarang). Jurnal Akuntansi, 1-15.

Fitriani. (2016). Pengaruh Pengalaman Kerja, Kompetensi, Independensi, Due Professional Care Dan Etika Auditor Terhadap Kualitas Audit (Studi Empiris Pada Auditor Inspektorat Kabupaten Boyolali dan Surakarta). Jurnal Akuntansi, 1-16.

Hanjani, A., dan Rahardja.(2014). Pengaruh Etika Auditor, Pengalaman Auditor, Fee Audit, dan Motivasi Auditor Terhadap Kualitas Audit (Studi pada Auditor KAP di Semarang. Diponegoro Journal Of Accounting, 3(2), 1-9 .

Institut Akuntan Publik Indonesia. (2011). Standar Profesional Akuntan Publik (SPAP). Jakarta: Salemba Empat.

Kamil, dkk. (2018). Pengaruh Etika Auditor, Pengalaman Auditor dan Fee Audit terhadap Kualitas Audit Studi Empiris pada Kantor Akuntan Publik (KAP) di Kota Bandung. Prosiding Akuntansi, 4(2), Universitas Islam Bandung: 783-795. ISSN : 2460-6561.

Kurnia, dkk. (2014). Pengaruh Kompetensi, Independensi, Tekanan Waktu, Dan Etika Auditor Terhadap Kualitas Audit. E-Journal Akuntansi, 1(2), 49-67.

Lestari, D.W. (2017). Pengaruh Fee Audit, Independensi, Kompetensi, Etika Auditor Dan Tekanan Anggaran Waktu Terhadap Kualitas Audit. Skripsi.Fakultas Ekonomi dan Bisnis. Institut Agama Islam Surakarta. 
Natawirani, P.R., dan Wirajaya, I.G.A. (2017). Pengaruh Kompleksitas Tugas, Independensi Dan Komitmen Profesional Pada Kualitas Audit. E-Jurnal Akuntansi,18(1), 735-762.

Rahayu, N.T. (2017). Pengaruh Independensi, Pengalaman, Due Professional Care, Akuntabilitas dan Kompetensi Terhadap Kualitas Audit (Studi Pada Kantor Akuntan Publik di Surakarta dan Semarang). Skripsi.Fakultas Ekonomi dan Bisnis. Universitas Muhammadiyah Surakarta.

Ratha, I. M.D.K., dan Ramantha, I.W. (2015). Pengaruh Due Professional Care, Akuntabilitas, Kompleksitas Audit, Dan Time Budget Pressure Terhadap Kualitas Audit. E-Jurnal Akuntansi Universitas Udayana, 13(1), 311-339.

Ridhawati, P. N. (2018). Pengaruh Independensi, Kompetensi, Due Professional Care, Akuntabilitas, Etika Profesi Dan Time Budget Pressure Terhadap Kualitas Audit (Studi Empiris Pada Kantor Kap Di Semarang). Skripsi.Fakultas Ekonomi. Universitas Katolik Soegijapranata. Semarang.

Sari, E.N. (2015). Pengaruh Kompetensi, Independensi Dan Due Professional Care Terhadap Kualitas Audit. Skripsi.Fakultas Ekonomi dan Bisnis. Universitas Islam Negeri Syarif Hidayatullah. Jakarta.

Susmiyanti. (2016). Pengaruh Fee Audit, Time Budget Pressure dan Kompleksitas Tugas Terhadap Kualitas Audit Dengan Pengalaman Auditor Sebagai Variabel Moderating. Skripsi. Universitas Negeri Yogyakarta: Yogyakarta. 